\title{
Aldosterone, Dexamethasone and Triamcinolone Activate African Lungfish Mineralocorticoid Receptor: Increased Activation After Removal of the Amino-Terminal Domain
}

\section{Yoshinao Katsu ( $\nabla$ ykatsu@sci.hokudai.ac.jp )}

Hokkaido University https://orcid.org/0000-0003-2625-4626

\section{Shin Oana}

Hokkaido University

Xiaozhi Lin

Hokkaido University https://orcid.org/0000-0002-8084-8145

\section{Susumu Hyodo}

The University of Tokyo

Michael E. Baker ( $\square$ mbaker@ucsd.edu )

University of California, San Diego https://orcid.org/0000-0003-4387-3269

\section{Research Article}

Keywords: Lungfish, Lobe-finned Fish, Terrestrial Vertebrates, Aldosterone evolution, mineralocorticoid receptor evolution, evolution

Posted Date: June 1st, 2021

DOI: https://doi.org/10.21203/rs.3.rs-573469/v1

License: (c) (i) This work is licensed under a Creative Commons Attribution 4.0 International License. Read Full License

Version of Record: A version of this preprint was published at The Journal of Steroid Biochemistry and Molecular Biology on November 1st, 2021. See the published version at https://doi.org/10.1016/j.jsbmb.2021.106024. 


\section{Abstract}

A distinct mineralocorticoid receptor (MR) ortholog first appears in cartilaginous fishes, such as sharks, skates, rays and chimaeras. Although aldosterone, the main physiological mineralocorticoid in humans and other terrestrial vertebrates, is a transcriptional activator of skate MR and elephant shark MR, aldosterone is not synthesized by cartilaginous fishes. Aldosterone, first appears in lungfish, which are lobe-finned fish that are forerunners of terrestrial vertebrates. Aldosterone activation of the MR regulates internal homeostasis of water, sodium and potassium, which was critical in the conquest of land by vertebrates. We studied transcriptional activation of the slender African lungfish (Protopterus dolloi) MR by aldosterone, other corticosteroids and progesterone and find that aldosterone, 11-deoxycorticosterone, 11-deoxycortisol and progesterone have half-maximal responses (EC50s) below $1 \mathrm{nM}$ and are potential physiological mineralocorticoids. In contrast, EC50s for corticosterone and cortisol were $23 \mathrm{nM}$ and 66 $\mathrm{nM}$, respectively. Unexpectedly, truncated lungfish MR, consisting of the DNA-binding domain, hinge domain and steroid-binding domain, had a stronger response to aldosterone, other corticosteroids and progesterone than did full-length lungfish MR, indicating that an allosteric action of the $\mathrm{N}$-terminal domain represses steroid activation of lungfish MR. This contrasts to human MR in which the N-terminal domain contains an activation function. BLAST searches of GenBank did not retrieve a GR ortholog, leading us to test dexamethasone and triamcinolone for activation of lungfish MR. At $10 \mathrm{nM}$, both synthetic glucocorticoids are about 4-fold stronger than $10 \mathrm{nM}$ aldosterone in activating full-length lungfish MR, leading us to propose that lungfish MR also functions as a GR.

\section{Introduction}

The mineralocorticoid receptor (MR) and glucocorticoid receptor (GR) belong to the nuclear receptor family, a diverse group of transcription factors that arose in multicellular animals [1-3]. The MR and GR have key roles in the physiology of humans and other terrestrial vertebrates and fish [4-11]. The MR and GR evolved from an ancestral corticoid receptor (CR) in a jawless fish (cyclostome), which has descendants in modern lampreys and hagfish [12-14]. A distinct MR and GR first appear in cartilaginous fishes (Chondrichthyes) [1, 13, 15-17], which diverged from bony vertebrates about 450 million years ago $[18,19]$.

Aldosterone is the main physiological mineralocorticoid in humans and other terrestrial vertebrates $[5,6$, $9,20-23]$. Aldosterone activation of the MR in the kidney regulates salt and water homeostasis by promoting sodium and water reabsorption and potassium secretion, a mechanism that conserves salt and water. Thus, it is puzzling that aldosterone is a potent transcriptional activator of lamprey and hagfish CRs [15], skate MR [16] and elephant shark MR $[13,24]$ because aldosterone is not synthesized by lampreys [15], cartilaginous fishes or ray finned fishes [25]. Aldosterone first appears in lungfish [26-28], which are lobe-finned fish that are forerunners of terrestrial vertebrates [29-31]. The key phylogenetic position of lungfish in the transition of vertebrates from water to land [27, 29, 30,32] and the role of the MR in maintaining internal electrolyte homeostasis $[5,8,33,34]$ motivated us to investigate the response of the slender African lungfish MR to aldosterone, cortisol and other corticosteroids (Fig. 1), as well as 
activation by progestins, which also activate elephant shark MR [24], ray-finned fish MR [35-39] and chicken MR $[24,40]$.

Our investigation also uncovered an unexpected role of the N-terminal domain (NTD) of lungfish MR in inhibiting transcriptional activation by steroids. Like other steroid receptors, lungfish MR is a multidomain protein, consisting of an NTD (domains A and B), a central DNA-binding domain (DBD) (domain C), a hinge domain (D) and a C-terminal ligand-binding domain (LBD) (domain E) [49-51] (Fig. 2). The NTD in the human MR contains an activation function domain (AF1), which is split into two segments [49-51]. (Fig. 2). As described below, we find that in contrast to human MR [24, 49, 51, 52], the NTD in full-length lungfish MR reduces steroid-mediated activation of lungfish MR, compared to truncated lungfish MR-CDE in cells transfected with a 3X-Tyrosine Amino Transferase (TAT3) promoter [53].

We also find that lungfish MR is activated by dexamethasone. At $10 \mathrm{nM}$, dexamethasone activates fulllength lungfish MR and truncated lungfish MR with a signal that is 4-fold and 6-fold stronger, respectively, than that of $10 \mathrm{nM}$ aldosterone. This strong response to dexamethasone and the absence of a lungfish GR sequence after a BLAST search of GenBank leads us to propose that lungfish MR also functions as a GR.

\section{Results}

\section{Transcriptional activation of full-length and truncated lungfish MR by corticosteroids, progestins and dexamethasone.}

We screened a panel of steroids (Fig. 1) at $10 \mathrm{nM}$ for transcriptional activation of full-length and truncated lungfish MR containing the CDE domains (MR-CDE) using two promoters: 2X-Mouse Mammary Tumor Virus (MMTV) [54, 55] and TAT3 [53], which along with plasmids for both lungfish MRs were transfected into HEK293 cells.

As shown in Fig. 3A, there was about 2 to 3 -fold activation by $10 \mathrm{nM}$ aldosterone, other corticosteroids or progesterone of full-length lungfish MR using the MMTV-luc reporter and less steroid activation of lungfish MR-CDE (Fig. 3B).

Interestingly, compared to activation of full-length lungfish MR with the MMTV promoter (Fig. 3A), transcriptional activation of full-length lungfish MR with a TAT3 promoter and $10 \mathrm{nM}$ aldosterone, other physiological corticosteroids or dexamethasone increased by about 1.5 to 2 -fold (Fig. 3C). Unexpectedly, lungfish MR-CDE with the TAT3 promoter had an additional 2-fold increase in activation by all corticosteroids (Fig. 3D). Progesterone activated lungfish MR in accord with the prediction of Fuller et al. $[37,39,56]$. Together, these experiments show that removal of the NTD increases corticosteroid and progesterone activation of lungfish MR in the presence of the TAT3 promoter.

Our results with dexamethasone, which activates human MR [52,57-59], were unexpected. To our surprise, compared to aldosterone, dexamethasone was about 3-fold and 6-fold more active, respectively, 
in activating full-length lungfish MR (Fig. 3C) and truncated lungfish MR (Fig. 3D) with the TAT3 promoter. Moreover, both cortisol and corticosterone have stronger fold-activation than does aldosterone of lungfish MR using the TAT3 promoter. Under these conditions, lungfish MR appears to have a GR-like response to steroids.

Plasmids for full-length lungfish MR or truncated lungfish MR (MR-CDE) were expressed in HEK293 cells with an MMTV-luciferase reporter or a TAT3-luciferase reporter. Transfected cells were treated with either $10 \mathrm{nM}$ aldosterone, cortisol, 11-deoxycortisol, corticosterone, 11-deoxycorticosterone, progesterone, dexamethasone or vehicle alone (DMSO). Results are expressed as means $\pm S E M, n=3$. Y-axis indicates fold-activation compared to the activity of control vector with vehicle alone as 1 . A. Full-length lungfish MR with MMTV-luciferase. B. Truncated lungfish MR (MR-CDE) with MMTV-luciferase. C. Full-length lungfish MR with TAT3-luciferase. D. Truncated lungfish MR (MR-CDE) with TAT3-luciferase.

\section{Spironolactone and eplerenone are transcriptional activators of lungfish MR.}

Because spironolactone, an antagonist of human MR, activates elephant shark MR [24], zebrafish MR [37, $40,60]$ and trout MR [38], we investigated spironolactone for activation of full-length lungfish MR and truncated lungfish MR-CDE. We also studied activation by eplerenone, another antagonist of human MR [61]. As shown in Fig. 4, both spironolactone and eplerenone activated lungfish MR with a TAT3 promoter, and there was a further increase in fold-activation by both steroids of lungfish MR-CDE.

\section{Concentration-dependent activation by corticosteroids and progestins of full-length and truncated lungfish MR.}

To gain a quantitative measure of corticosteroid and progestin activation of full-length and truncated lungfish MR, we determined the concentration dependence of transcriptional activation by corticosteroids and progestins of full-length lungfish MR and lungfish MR-CDE using TAT3 (Fig. 5). This data was used to calculate a half maximal response (EC50) for steroid activation of lungfish MR with a TAT3 promoter (Table 1). For full-length lungfish MR, the four lowest EC50s were for aldosterone (0.04nM), 11deoxycorticosterone $(0.04 \mathrm{nM}), 11$-deoxycortisol $(0.17 \mathrm{nM})$ and progesterone $(0.03 \mathrm{nM})$. These low EC50s are consistent with a physiological role for one or more of these steroids as ligand for lungfish MR. In contrast, corticosterone and cortisol, two physiological corticosteroids in terrestrial vertebrates, had EC50s of $23.1 \mathrm{nM}$ and $66.1 \mathrm{nM}$, respectively. Two synthetic glucocorticoids, dexamethasone and triamcinolone, had EC50s of $4.7 \mathrm{nM}$ and $1.3 \mathrm{nM}$, respectively.

For truncated lungfish MR, there were similar low EC50s for aldosterone $(0.24 \mathrm{nM}), 11$ deoxycorticosterone $(0.013 \mathrm{nM}), 11$-deoxycortisol $(0.27 \mathrm{nM})$ and progesterone $(0.04 \mathrm{nM})$. EC50s for corticosterone and cortisol were $85.5 \mathrm{nM}$ and $86.7 \mathrm{nM}$, respectively. EC50s for dexamethasone and triamcinolone were $7.7 \mathrm{nM}$ and $2.4 \mathrm{nM}$, respectively.

Overall, these results reveal that the EC50s of aldosterone, 11-deoxycorticosterone, 11-deoxycortisol and progesterone for full-length lungfish MR and lungfish MR-CDE are similar and that one or more of these 
steroids could be a physiological mineralocorticoid in lungfish. Although EC50s for full-length lungfish MR of triamcinolone and dexamethasone were at least 10-fold higher than that of aldosterone, deoxycorticosterone, 11-deoxycortisol and progesterone, compared to these steroids, dexamethasone and triamcinolone have a several fold higher activation of full-length and truncated lungfish MR (Fig. 5). Consistent with data in Fig. 3, deletion of the NTD to form truncated lungfish MR-CDE increased foldactivation by aldosterone, the other corticosteroids, progesterone, dexamethasone and triamcinolone. However, deletion of the NTD did not have a large effect on their EC50s.

Table 1

EC50 values for steroid activation of full-length and truncated lungfish MR with the TAT3 promoter.

\begin{tabular}{|lllll|}
\hline & Aldosterone & $\begin{array}{l}11- \\
\text { deoxycorticosterone }\end{array}$ & $\begin{array}{l}11- \\
\text { deoxycortisol }\end{array}$ & Progesterone \\
\hline MR-full length & EC50 & EC50 & EC50 & EC50 \\
\hline $\begin{array}{l}\text { 95\% confidence } \\
\text { interval }\end{array}$ & $0.04 \mathrm{nM}$ & $0.04 \mathrm{nM}$ & $0.17 \mathrm{nM}$ & $0.03 \mathrm{nM}$ \\
\hline MR-CDE & $\begin{array}{l}0.02-0.07 \\
\mathrm{nM}\end{array}$ & $0.02-0.09 \mathrm{nM}$ & $0.1-0.3 \mathrm{nM}$ & $0.02-0.06 \mathrm{nM}$ \\
\hline $\begin{array}{l}\text { 95\% confidence } \\
\text { interval }\end{array}$ & $0.24 \mathrm{nM}$ & $0.13 \mathrm{nM}$ & $0.27 \mathrm{nM}$ & $0.044 \mathrm{nM}$ \\
\hline
\end{tabular}

\begin{tabular}{|lllll|}
\hline & Corticosterone & Cortisol & Triamcinolone & Dexamethasone \\
\hline & EC50 & EC50 & EC50 & EC50 \\
\hline MR-full length & $23.1 \mathrm{nM}$ & $66.1 \mathrm{nM}$ & $1.3 \mathrm{nM}$ & $4.7 \mathrm{nM}$ \\
\hline 95\% confidence interval & $11.3-47.1 \mathrm{nM}$ & $44.5-98.4 \mathrm{nM}$ & $0.9-1.9 \mathrm{nM}$ & $3.3-6.9 \mathrm{nM}$ \\
\hline MR-CDE & $85.5 \mathrm{nM}$ & $86.7 \mathrm{nM}$ & $2.4 \mathrm{nM}$ & $7.7 \mathrm{nM}$ \\
\hline 95\% confidence interval & $60.0-121.8 \mathrm{nM}$ & $74.3-101.2 \mathrm{nM}$ & $2.1-2.8 \mathrm{nM}$ & $6.6-9.1 \mathrm{nM}$ \\
\hline
\end{tabular}

Transcriptional activation of full-length and truncated human MR and full-length and truncated elephant shark MR by corticosteroids and progestins.

To gain an evolutionary perspective on activation of lungfish MR by steroids, we screened a panel of steroids, at $10 \mathrm{nM}$, for transcriptional activation of full-length human and elephant shark MRs and truncated human and elephant shark MR-CDEs using two reporters: MMTV-luc and TAT3-luc.

Comparison of human MR and lungfish MR.

Overall, compared to lungfish MR, fold activation of human MR was significantly higher for aldosterone and other corticosteroids. For example, compared to 2 -fold activation by aldosterone of full-length 
lungfish MR with the MMTV promoter (Fig. 3A), activation of full-length human MR by aldosterone was about 70-fold with the MMTV promoter (Fig. 6A). Although fold-activation by steroids for truncated human MR (Fig. 6B) decreased compared to full-length human MR (Fig. 6A), activation by aldosterone and other corticosteroids of truncated human MR with the MMTV promoter (Fig. 6B) was about 7-fold higher than for truncated lungfish MR (Fig. 3B).

Unlike for lungfish MR, deletion of the NTD in human MR resulted in a loss of activation by aldosterone and other corticosteroids for human MR-CDE with both promoters (Fig. 6A-D), consistent with the presence of two activation function domains in the NTD (Fig. 2) [49-52]. The relative loss of activation of human MR was greater with the MMTV promoter than with the TAT3 promoter. For example, at $10 \mathrm{nM}$ aldosterone, activation of full-length human MR with the MMTV reporter was 70-fold (Fig. 6A), which decreased to 14-fold for human MR-CDE (Fig. 6B). In contrast, at $10 \mathrm{nM}$ aldosterone, fold-activation of human MR-CDE with the TAT3 promoter was about $75 \%$ of activity for full-length human MR (Fig. 6 C, D). However, 11-deoxycorticosterone and 11-deoxycortisol lost substantial activity for human MR-CDE with the MMTV and TAT3 promoters (Fig. 6D).

There also was higher fold-activation by aldosterone of full-length and truncated human MR with the TAT3 promoter (Fig. 6C, D) compared to full-length and truncated lungfish MR (Fig. 3C, D). Aldosterone activation of full-length human MR with the TAT3 promoter (Fig. 6C) was about 45-fold higher than that for full-length lungfish MR with the TAT3 promoter (Fig. 3C). Aldosterone activation of human MR-CDE with the TAT3 promoter (Fig. 6D) was about 15-fold higher than that for lungfish MR-CDE (Fig. 3D).

The relative activation by aldosterone and dexamethasone of human MR and lungfish MR was reversed. Aldosterone was more active than dexamethasone in stimulating transcription by full-length human MR and human MR-CDE with the TAT3 promoter (Fig. 6C, D). In contrast, for lungfish MR dexamethasone was more active than aldosterone for full-length lungfish MR and lungfish MR-CDE with the TAT3 promoter (Fig. 3C, D).

\section{Comparison of elephant shark MR and lungfish MR.}

Activation by corticosteroids and progesterone of elephant shark MR with the MMTV promoter has some similarities with their activation of lungfish MR. Like lungfish MR, corticosteroids have a similar activation of about 10-fold for full-length and truncated elephant shark MR, with little difference in potency among the corticosteroids. However, unlike lungfish MR, aldosterone is stronger than dexamethasone in activating full-length and truncated elephant shark MR with the MMTV promoter (Fig. 6E, F).

At a $10 \mathrm{nM}$ steroid concentration, aldosterone and other corticosteroids activated full-length elephant shark MR with the TAT3 promoter by 9 to 12 -fold (Fig. 6G), which was similar to activation with the MMTV promoter (Fig. 6E). Activation of full-length elephant shark MR by progesterone was about 5-fold with the TAT3 and MMTV promoters (Fig. 6E, G). Aldosterone was about 2-fold more active than dexamethasone. 
However, deletion of the NTD from elephant shark MR resulted in a significant increase is activation by steroids in the presence of the TAT3 promoter (Fig. $6 \mathrm{H})$. Thus, truncated elephant shark MR with the TAT3 promoter was activated from 300 to 350 -fold by aldosterone and other corticosteroids and about 200-fold by progesterone and dexamethasone (Fig. $6 \mathrm{H}$ ), indicating that like lungfish MR, the NTD in elephant shark inhibits activation by corticosteroids. However, unlike lungfish MR, compared to aldosterone, dexamethasone was less active for full-length and truncated elephant shark MR with the MMTV promoter and truncated elephant shark MR with the TAT3 promoter.

\section{Does lungfish contain a separate GR gene?}

We used sequences of human GR, coelacanth GR and elephant shark GR as probes in a BLAST search of GenBank and did not retrieve a lungfish GR sequence. The absence of a lungfish GR ortholog coupled with the strong response of lungfish MR to dexamethasone and triamcinolone (Fig. 5) leads us to propose that lungfish MR also functions as a GR.

\section{Discussion}

Dobzhansky's aphorism "Nothing in Biology Makes Sense Except in the Light of Evolution" [62] explains the importance of the evolution of aldosterone in lungfish because aldosterone activation of the kidney MR in terrestrial vertebrates regulates sodium, potassium and water transport, which is critical in maintaining internal electrolyte homeostasis in terrestrial vertebrates $[30,34,63-65]$ an activity that was important in the transition from water to land. Here we report that aldosterone, 11-deoxycorticosterone, and progesterone have EC50s below $1 \mathrm{nM}$ for lungfish MR (Table 1), which makes these steroids potential physiological ligands for lungfish MR. Another potential physiological steroid is 11deoxycortisol, which is a steroid for the CR in Atlantic sea lamprey [42, 43]. 11-deoxycortisol has EC50 of $0.17 \mathrm{nM}$ for full-length lungfish MR (Table 1).

A functional advantage of 11-deoxycorticosterone, 11-deoxycortisol and progesterone as ligands for the MR is that they lack an $11 \beta$-hydroxyl group, and thus, like aldosterone, they are inert to $11 \beta$ hydroxysteroid dehydrogenase-type 2, unlike cortisol and corticosterone [66-69]. Indeed, this inertness to $11 \beta$-hydroxysteroid dehydrogenase-type 2 and the low EC50s of these steroids for lungfish MR suggests that more than one corticosteroid and progesterone [39] may be physiological mineralocorticoids.

Like ray-finned fish MRs $[24,37,38,60]$ and elephant shark MR $[24,39]$, lungfish MR is activated by spironolactone (Fig. 4), and, as reported here, by eplerenone [47, 48, 61].

We also find important differences between the response of lungfish MR and human MR to aldosterone, 11-deoxycorticosterone, 11-deoxycortisol and progesterone, indicating that further selectivity for aldosterone in human MR occurred during the evolution of terrestrial vertebrates $[13,15,37,40,52,69$, 70]. 
An unexpected difference between lungfish MR and human MR is the substantial increase in foldactivation by steroids of lungfish MR after deletion of the NTD, in contrast to human MR in which the NTD contains an activation function domain (Fig. 2) [49-52]. Deletion of the NTD in elephant shark MR also resulted in a substantial increase in fold-activation by corticosteroids and progesterone using the TAT3 promoter (Fig. 6), but not for the MMTV promoter [17]. These data with lungfish MR and elephant shark MR suggest that early in the evolution of the MR there was an allosteric interaction between the LBD and NTD $[71,72]$ that repressed steroid activation of the MR, and that the activation function in the NTD as found in human MR [49-52] evolved later in terrestrial vertebrates, along with changes in steroid specificity, such loss of MR activation by progesterone $[37,39,70]$. The different responses of full-length and truncated lungfish MR, human MR and elephant shark MR with the MMTV and TAT3 promoters indicate that the NTD and the promoter are important regulators of steroid activation of these MRs. Corticosteroid activation of these MRs in the presence of other promoters merits investigation.

The stronger response of lungfish MR to dexamethasone compared to aldosterone and the absence a lungfish GR ortholog sequence are puzzling. At a $10 \mathrm{nM}$ concentration, fold-activation by dexamethasone and triamcinolone is substantially higher than that of cortisol, corticosterone, as well as aldosterone, 11deoxycorticosterone, 11-deoxycortisol and progesterone for lungfish MR (Fig. 5). One explanation is that lungfish MR also has a GR function.

\section{Materials And Methods Chemical reagents}

Aldosterone, cortisol, corticosterone, 11-deoxycorticosterone, 11-deoxycortisol and progesterone, spironolactone and eplerenone were purchased from Sigma-Aldrich. For reporter gene assays, all hormones were dissolved in dimethyl-sulfoxide (DMSO); the final DMSO concentration in the culture medium did not exceed $0.1 \%$.

\section{Animal}

A slender spotted African lungfish, Protopterus dolloi, was purchased from a local commercial supplier. Lungfish were anesthetized in freshwater containing $0.02 \%$ ethyl 3 -aminobenzoate methane-sulfonate from Sigma-Aldrich, and tissue samples were quickly dissected and frozen in liquid nitrogen. Animal handling procedures conformed to the guidelines set forth by the Institutional Animal Care and Use Committee at the University of Tokyo.

\section{Molecular cloning of lungfish mineralocorticoid receptor}

Two conserved amino acid regions, GCHYGV and LYFAPD of vertebrate MRs were selected and degenerate oligonucleotides were used as primers for PCR. First-strand CDNA was synthesized from $2 \mu \mathrm{g}$ of total RNA isolated from the liver after amplification, and an additional primer set (CKVFFK and LYFAPD) was used for the second PCR. The amplified DNA fragments were subcloned with TA-cloning plasmid pGEM-T Easy vector, sequenced using a BigDye terminator Cycle Sequencing-kit with $\mathrm{T7}$ and 
SP6 primers, and analyzed on the 3130 Genetic Analyzer (Applied Biosystems). The 5'-and 3'-ends of the mineralocorticoid receptor cDNAs were amplified by rapid amplification of the cDNA end (RACE) using a SMART RACE cDNA Amplification kit. Genbank accessions for this lungfish MR are: Nucleotide ID: LC630795 and Protein ID: BCV19931.

\section{Construction of plasmid vectors}

The full-length and truncated MRs were amplified by PCR with KOD DNA polymerase. The PCR products were gel-purified and ligated into pcDNA3.1 vector (Invitrogen). The truncated MR proteins were designed to possess methionine and valine residues at the N-terminus and contain a DNA-binding domain, a hingeregion, and a ligand-binding domain. The truncated MRs were amplified by PCR with KOD DNA polymerase by using the following primers: lungfish MR forward primer (5'-

CAAGCTTACCATGGTGTGTCTGGTGTGTGGTGACGAAG-3' containing Hindll site) and lungfish MR reverse primer (5'-CCTACTTCCTGTGAAAGTACAATGAC - 3' containing stop codon), human MR forward primer (5'-CGGATCCACCATGGTGTGTTTGGTGTGTGGGGATGAG-3' containing BamHl site) and human MR reverse primer (5'-CTCACTTCCGGTGGAAGTAGAGCGGC - 3' containing stop codon). The amplified DNA fragments were subcloned with TA-cloning plasmid pGEM-T Easy vector and sequenced, and then subcloned into pcDNA 3.1 vector by using Hindll-Notl sites for lungfish MR truncated form or BamHI-Notl sites for human MR truncated form. Mouse mammary tumor virus-long terminal repeat (MMTV-LTR) was amplified from pMSG vector by PCR, and inserted into PGL3-basic vector containing the Photinus pyralis lucifease gene. 3X-Tyrosine Amino Transferase (TAT3) promoter containing reporter vector named pGL4.23-TAT3-Luc was constructed as described previously [53]. All cloned DNA sequences were verified by sequencing.

\section{Transactivation assay and statistical methods}

Transfection and reporter assays were carried out in HEK293 cells, as described previously [40, 73]. All experiments were performed in triplicate. The values shown are mean \pm SEM from three separate experiments, and dose-response data, which were used to calculate the half maximal response (EC50) for each steroid, were analyzed using GraphPad Prism.

\section{Declarations}

\section{DECLARATION OF INTEREST}

We have no conflict of interest.

\section{ACKNOWLEDGEMENT}

We thank Peter Fuller, Ron de Kloet, Patrick Prunet and Bernard Rossier for constructive comments about an earlier version of this manuscript. 


\section{AUTHOR CONTRIBUTIONS}

Y.K., S.O., and M.E.B. carried out the research and analyzed data. S.H. aided in the collection of animals. X.L. constructed plasmid DNAs used in this study. Y.K. and M.E.B. conceived and designed the experiments. Y.K. and M.E.B. wrote the paper. All authors gave final approval for publication.

\section{FUNDING}

Y.K. was supported in part by Grants-in-Aid for Scientific Research [19K067309] from the Ministry of Education, Culture, Sports, Science and Technology of Japan, and Takeda Science Foundation. M.E.B. was supported by Research fund \#3096.

\section{References}

1. Baker ME, Nelson DR, Studer RA. Origin of the response to adrenal and sex steroids: Roles of promiscuity and co-evolution of enzymes and steroid receptors. J Steroid Biochem Mol Biol. 2015;151:12-24. doi:10.1016/j.jsbmb.2014.10.020.

2. Evans RM. The steroid and thyroid hormone receptor superfamily. Science. 1988;240(4854):889-895. doi:10.1126/science.3283939.

3. Bridgham JT, Eick GN, Larroux C, et al. Protein evolution by molecular tinkering: diversification of the nuclear receptor superfamily from a ligand-dependent ancestor. PLoS Biol. 2010;8(10):e1000497. Published 2010 Oct 5. doi:10.1371/journal.pbio.1000497.

4. Baker ME, Funder JW, Kattoula SR. Evolution of hormone selectivity in glucocorticoid and mineralocorticoid receptors [published correction appears in J Steroid Biochem Mol Biol. 2014 Jan;139:104]. J Steroid Biochem Mol Biol. 2013;137:57-70. doi:10.1016/j.jsbmb.2013.07.009.

5. Lifton RP, Gharavi AG, Geller DS. Molecular mechanisms of human hypertension. Cell. 2001;104(4):545-556. doi:10.1016/s0092-8674(01)00241-0.

6. Shibata S. 30 YEARS OF THE MINERALOCORTICOID RECEPTOR: Mineralocorticoid receptor and $\mathrm{NaCl}$ transport mechanisms in the renal distal nephron. J Endocrinol. 2017;234(1):T35-T47. doi:10.1530/JOE-16-0669.

7. Jaisser F, Farman N. Emerging Roles of the Mineralocorticoid Receptor in Pathology: Toward New Paradigms in Clinical Pharmacology. Pharmacol Rev. 2016;68(1):49-75. doi:10.1124/pr.115.011106.

8. Hanukoglu I, Hanukoglu A. Epithelial sodium channel (ENaC) family: Phylogeny, structure-function, tissue distribution, and associated inherited diseases. Gene. 2016;579(2):95-132. doi:10.1016/j.gene.2015.12.061. 
9. Joëls M, de Kloet ER. 30 YEARS OF THE MINERALOCORTICOID RECEPTOR: The brain mineralocorticoid receptor: a saga in three episodes. J Endocrinol. 2017 Jul;234(1):T49-T66. doi: 10.1530/JOE-16-0660. PMID: 28634266.

10. Gross KL, Cidlowski JA. Tissue-specific glucocorticoid action: a family affair. Trends Endocrinol Metab. 2008;19(9):331-339. doi:10.1016/j.tem.2008.07.009.

11. Weikum ER, Knuesel MT, Ortlund EA, Yamamoto KR. Glucocorticoid receptor control of transcription: precision and plasticity via allostery. Nat Rev Mol Cell Biol. 2017;18(3):159-174. doi:10.1038/nrm.2016.152.

12. Thornton JW. Evolution of vertebrate steroid receptors from an ancestral estrogen receptor by ligand exploitation and serial genome expansions. Proc Natl Acad Sci U S A. 2001 May 8;98(10):5671-6. doi: 10.1073/pnas.091553298. Epub 2001 May 1. PMID: 11331759; PMCID: PMC33271.

13. Baker ME, Katsu Y. 30 YEARS OF THE MINERALOCORTICOID RECEPTOR: Evolution of the mineralocorticoid receptor: sequence, structure and function. J Endocrinol. 2017;234(1):T1-T16. doi:10.1530/JOE-16-0661.

14. Osório J, Rétaux S. The lamprey in evolutionary studies. Dev Genes Evol. 2008 May;218(5):221-35. doi: 10.1007/s00427-008-0208-1. Epub 2008 Feb 15. PMID: 18274775.

15. Bridgham JT, Carroll SM, Thornton JW. Evolution of hormone-receptor complexity by molecular exploitation. Science. 2006;312(5770):97-101. doi:10.1126/science.1123348.

16. Carroll SM, Bridgham JT, Thornton JW. Evolution of hormone signaling in elasmobranchs by exploitation of promiscuous receptors. Mol Biol Evol. 2008;25(12):2643-2652. doi:10.1093/molbev/msn204.

17. Katsu Y, Shariful IMD, Lin X, Takagi W, Urushitani H, Kohno S, Hyodo S, Baker ME. N-terminal Domain Regulates Steroid Activation of Elephant Shark Glucocorticoid and Mineralocorticoid Receptors. J Steroid Biochem Mol Biol. 2021 Feb 27:105845. doi: 10.1016/j.jsbmb.2021.105845. Epub ahead of print. PMID: 33652098.

18. Inoue JG, Miya M, Lam K, et al. Evolutionary origin and phylogeny of the modern holocephalans (Chondrichthyes: Chimaeriformes): a mitogenomic perspective. Mol Biol Evol. 2010;27(11):25762586. doi:10.1093/molbev/msq147.

19. Venkatesh B, Lee AP, Ravi V, et al. Elephant shark genome provides unique insights into gnathostome evolution [published correction appears in Nature. 2014 Sep 25;513(7519):574]. Nature. 2014;505(7482):174-179. doi:10.1038/nature12826.

20. Funder JW. Aldosterone and Mineralocorticoid Receptors-Physiology and Pathophysiology. Int J Mol Sci. 2017 May 11;18(5):1032. doi: 10.3390/ijms18051032. PMID: 28492512; PMCID: PMC5454944.

21. Hawkins UA, Gomez-Sanchez EP, Gomez-Sanchez CM, Gomez-Sanchez CE. The ubiquitous mineralocorticoid receptor: clinical implications. Curr Hypertens Rep. 2012;14(6):573-580. doi:10.1007/s11906-012-0297-0.

22. Rossier BC, Baker ME, Studer RA. Epithelial sodium transport and its control by aldosterone: the story of our internal environment revisited. Physiol Rev. 2015;95(1):297-340. 
doi:10.1152/physrev.00011.2014.

23. Arriza JL, Weinberger C, Cerelli G, et al. Cloning of human mineralocorticoid receptor complementary DNA: structural and functional kinship with the glucocorticoid receptor. Science.

1987;237(4812):268-275. doi:10.1126/science.3037703.

24. Katsu Y, Kohno S, Oka K, et al. Transcriptional activation of elephant shark mineralocorticoid receptor by corticosteroids, progesterone, and spironolactone. Sci Signal. 2019;12(584):eaar2668. Published 2019 Jun 4. doi:10.1126/scisignal.aar2668, (n.d.).

25. Jiang JQ, Young G, Kobayashi T, Nagahama Y. Eel (Anguilla japonica) testis 11beta-hydroxylase gene is expressed in interrenal tissue and its product lacks aldosterone synthesizing activity. Mol Cell Endocrinol. 1998;146(1-2):207-211. doi:10.1016/s0303-7207(98)00147-6.

26. Joss JM, Itahara Y, Watanabe TX, Nakajima K, Takei Y. Teleost-type angiotensin is present in Australian lungfish, Neoceratodus forsteri. Gen Comp Endocrinol. 1999;114(2):206-212. doi:10.1006/gcen.1999.7246.

27. Joss JM. Lungfish evolution and development. Gen Comp Endocrinol. 2006 Sep 15;148(3):285-9. doi: 10.1016/j.ygcen.2005.10.010. Epub 2005 Dec 7. PMID: 16337631.

28. Uchiyama M, Maejima S, Yoshie S, Kubo Y, Konno N, Joss JM. The epithelial sodium channel in the Australian lungfish, Neoceratodus forsteri (Osteichthyes: Dipnoi). Proc Biol Sci. 2012;279(1748):4795-4802. doi:10.1098/rspb.2012.1945.

29. Meyer A, Schloissnig S, Franchini P, Du K, Woltering JM, Irisarri I, Wong WY, Nowoshilow S, Kneitz S, Kawaguchi A, Fabrizius A, Xiong P, Dechaud C, Spaink HP, Volff JN, Simakov O, Burmester T, Tanaka EM, Schartl M. Giant lungfish genome elucidates the conquest of land by vertebrates. Nature. 2021 Feb;590(7845):284-289. doi: 10.1038/s41586-021-03198-8. Epub 2021 Jan 18. PMID: 33461212; PMCID: PMC7875771.

30. Biscotti MA, Gerdol M, Canapa A, Forconi M, Olmo E, Pallavicini A, Barucca M, Schartl M. The Lungfish Transcriptome: A Glimpse into Molecular Evolution Events at the Transition from Water to Land. Sci Rep. 2016 Feb 24;6:21571. doi: 10.1038/srep21571. PMID: 26908371; PMCID: PMC4764851.

31. Brinkmann H, Venkatesh B, Brenner S, Meyer A. Nuclear protein-coding genes support lungfish and not the coelacanth as the closest living relatives of land vertebrates. Proc Natl Acad Sci U S A. 2004 Apr 6;101(14):4900-5. doi: 10.1073/pnas.0400609101. Epub 2004 Mar 22. PMID: 15037746; PMCID: PMC387346.

32. Wang K, Wang J, Zhu C, Yang L, Ren Y, Ruan J, Fan G, Hu J, Xu W, Bi X, Zhu Y, Song Y, Chen H, Ma T, Zhao R, Jiang H, Zhang B, Feng C, Yuan Y, Gan X, Li Y, Zeng H, Liu Q, Zhang Y, Shao F, Hao S, Zhang H, Xu X, Liu X, Wang D, Zhu M, Zhang G, Zhao W, Qiu Q, He S, Wang W. African lungfish genome sheds light on the vertebrate water-to-land transition. Cell. 2021 Feb 4:S0092-8674(21)00090-8. doi: 10.1016/j.cell.2021.01.047. Epub ahead of print. PMID: 33545087.

33. McCormick SD, Bradshaw D. Hormonal control of salt and water balance in vertebrates. Gen Comp Endocrinol. 2006 May 15;147(1):3-8. doi: 10.1016/j.ygcen.2005.12.009. Epub 2006 Feb 2. PMID: 
16457828.

34. Rossier BC. Osmoregulation during Long-Term Fasting in Lungfish and Elephant Seal: Old and New Lessons for the Nephrologist. Nephron. 2016;134(1):5-9. doi: 10.1159/000444307. Epub 2016 Feb 23. PMID: 26901864.

35. Sugimoto A, Oka K, Sato R, Adachi S, Baker ME, Katsu Y. Corticosteroid and progesterone transactivation of mineralocorticoid receptors from Amur sturgeon and tropical gar. Biochem J. 2016;473(20):3655-3665. doi:10.1042/BCJ20160579.

36. Katsu Y, Baker ME. Progesterone activation of zebrafish mineralocorticoid receptor may influence growth of some transplanted tumors. Proc Natl Acad Sci U S A. 2018;115(13):E2908-E2909. doi:10.1073/pnas.1802441115.

37. Fuller PJ, Yao YZ, Jin R, et al. Molecular evolution of the switch for progesterone and spironolactone from mineralocorticoid receptor agonist to antagonist. Proc Natl Acad Sci U S A. 2019;116(37):18578-18583. doi:10.1073/pnas.1903172116, (n.d.).

38. Sturm A, Bury N, Dengreville L, et al. 11-deoxycorticosterone is a potent agonist of the rainbow trout (Oncorhynchus mykiss) mineralocorticoid receptor. Endocrinology. 2005;146(1):47-55. doi:10.1210/en.2004-0128.

39. Baker ME, Katsu Y. Progesterone: An enigmatic ligand for the mineralocorticoid receptor. Biochem Pharmacol. 2020;177:113976. doi:10.1016/j.bcp.2020.113976.

40. Katsu Y, Oka K, Baker ME. Evolution of human, chicken, alligator, frog, and zebrafish mineralocorticoid receptors: Allosteric influence on steroid specificity. Sci Signal. 2018;11(537):eaao1520. Published 2018 Jul 3. doi:10.1126/scisignal.aao1.

41. Baker ME, Funder JW, Kattoula SR. Evolution of hormone selectivity in glucocorticoid and mineralocorticoid receptors [published correction appears in J Steroid Biochem Mol Biol. 2014 Jan;139:104]. J Steroid Biochem Mol Biol. 2013;137:57-70. doi:10.1016/j.jsbmb.2013.07.009.

42. Close DA, Yun SS, McCormick SD, Wildbill AJ, Li W. 11-deoxycortisol is a corticosteroid hormone in the lamprey. Proc Natl Acad Sci U S A. 2010 Aug 3;107(31):13942-7. doi: 10.1073/pnas.0914026107. Epub 2010 Jul 19. PMID: 20643930; PMCID: PMC2922276.

43. Shaughnessy CA, Barany A, McCormick SD. 11-Deoxycortisol controls hydromineral balance in the most basal osmoregulating vertebrate, sea lamprey (Petromyzon marinus). Sci Rep. 2020;10(1):12148. Published 2020 Jul 22. doi:10.1038/s41598-020-69061-4.

44. Bridgham JT, Carroll SM, Thornton JW. Evolution of hormone-receptor complexity by molecular exploitation. Science. 2006;312(5770):97-101. doi:10.1126/science.1123348.

45. Conneely OM, Mulac-Jericevic B, DeMayo F, Lydon JP, O'Malley BW. Reproductive functions of progesterone receptors. Recent Prog Horm Res. 2002;57:339-355. doi:10.1210/rp.57.1.339.

46. Publicover S, Barratt C. Reproductive biology: Progesterone's gateway into sperm [published correction appears in Nature. 2011 Mar 31;471(7340):589]. Nature. 2011;471(7338):313-314. doi:10.1038/471313a. 
47. Epstein M, Calhoun DA. Aldosterone blockers (mineralocorticoid receptor antagonism) and potassium-sparing diuretics. J Clin Hypertens (Greenwich). 2011 Sep;13(9):644-8. doi:

10.1111/j.1751-7176.2011.00511.x. Epub 2011 Aug 9. PMID: 21896143.

48. Kolkhof P, Bärfacker L. 30 YEARS OF THE MINERALOCORTICOID RECEPTOR: Mineralocorticoid receptor antagonists: 60 years of research and development. J Endocrinol. 2017 Jul;234(1):T125T140. doi: 10.1530/JOE-16-0600. PMID: 28634268; PMCID: PMC5488394.

49. Fuse $\mathrm{H}$, Kitagawa $\mathrm{H}$, Kato $\mathrm{S}$. Characterization of transactivational property and coactivator mediation of rat mineralocorticoid receptor activation function-1 (AF-1). Mol Endocrinol. 2000 Jun;14(6):889-99. doi: 10.1210/mend.14.6.0467. PMID: 10847590.

50. Fischer K, Kelly SM, Watt K, Price NC, McEwan IJ. Conformation of the Mineralocorticoid Receptor NTerminal Domain: Evidence for Induced and Stable Structure. Mol Endocrinol. 2010 Oct;24(10):193548. Doi: 10.1210/Me.2010-0005. Epub 2010 Aug 4. PMID: 20685853; PMCID: PMC5417395.".

51. Pascual-Le Tallec $L$, Lombès $M$. The mineralocorticoid receptor: a journey exploring its diversity and specificity of action. Mol Endocrinol. 2005 Sep;19(9):2211-21. doi: 10.1210/me.2005-0089. Epub 2005 Mar 31. PMID: 15802372.

52. Rupprecht R, Arriza JL, Spengler D, et al. Transactivation and synergistic properties of the mineralocorticoid receptor: relationship to the glucocorticoid receptor. Mol Endocrinol. 1993;7(4):597603. doi:10.1210/mend.7.4.8388999.

53. Iñiguez-Lluhí JA, Pearce D. A common motif within the negative regulatory regions of multiple factors inhibits their transcriptional synergy. Mol Cell Biol. 2000 Aug;20(16):6040-50. doi: 10.1128/mcb.20.16.6040-6050.2000. PMID: 10913186; PMCID: PMC86080.

54. Beato M, Arnemann J, Chalepakis G, Slater E, Willmann T. Gene regulation by steroid hormones. J Steroid Biochem. 1987;27(1-3):9-14. doi: 10.1016/0022-4731(87)90288-3. PMID: 2826895.

55. Cato AC, Skroch P, Weinmann J, Butkeraitis P, Ponta H. DNA sequences outside the receptor-binding sites differently modulate the responsiveness of the mouse mammary tumour virus promoter to various steroid hormones. EMBO J. 1988 May;7(5):1403-10. PMID: 2842149; PMCID: PMC458390.

56. Fuller PJ, Yao Y, Yang J, Young MJ. Mechanisms of ligand specificity of the mineralocorticoid receptor. J Endocrinol. 2012 Apr;213(1):15-24. doi: 10.1530/JOE-11-0372. Epub 2011 Dec 12. PMID: 22159507.

57. Lombes M, Kenouch S, Souque A, Farman N, Rafestin-Oblin ME. The Mineralocorticoid Receptor Discriminates Aldosterone from Glucocorticoids Independently of the 11 Beta-Hydroxysteroid Dehydrogenase. Endocrinology. 1994;135(3):834-840. Doi:10.1210/Endo.135.3.8070376.

58. Hellal-Levy C, Couette B, Fagart J, Souque A, Gomez-Sanchez C, Rafestin-Oblin M. Specific hydroxylations determine selective corticosteroid recognition by human glucocorticoid and mineralocorticoid receptors. FEBS Lett. 1999;464(1-2):9-13. doi:10.1016/s0014-5793(99)01667-1.

59. Mani O, Nashev LG, Livelo C, Baker ME, Odermatt A. Role of Pro-637 and Gln-642 in human glucocorticoid receptors and Ser-843 and Leu-848 in mineralocorticoid receptors in their differential 
responses to cortisol and aldosterone. J Steroid Biochem Mol Biol. 2016 May;159:31-40. doi: 10.1016/j.jsbmb.2016.02.017. Epub 2016 Feb 22. PMID: 26907965.

60. Pippal JB, Cheung CM, Yao YZ, Brennan FE, Fuller PJ. Characterization of the zebrafish (Danio rerio) mineralocorticoid receptor. Mol Cell Endocrinol. 2011 Jan 30;332(1-2):58-66. doi:

10.1016/j.mce.2010.09.014. Epub 2010 Oct 12. PMID: 20932876.

61. Kiilerich P, Triqueneaux G, Christensen NM, et al. Interaction between the trout mineralocorticoid and glucocorticoid receptors in vitro. J Mol Endocrinol. 2015;55(1):55-68. doi:10.1530/JME-15-0002.

62. Dobzhansky.T (1973) Nothing in Biology Makes Sense except in the Light of Evolution. Am Biol Teach 35(3):125-129.

63. Fournier D, Luft FC, Bader M, Ganten D, Andrade-Navarro MA. Emergence and evolution of the reninangiotensin-aldosterone system. J Mol Med (Berl). 2012 May;90(5):495-508. doi: 10.1007/s00109012-0894-z. Epub 2012 Apr 14. PMID: 22527880; PMCID: PMC3354321.

64. Vize PD, Smith HW. A Homeric view of kidney evolution: A reprint of H.W. Smith's classic essay with a new introduction. Evolution of the kidney. 1943. Anat Rec A Discov Mol Cell Evol Biol. 2004;277(2):344-354. doi:10.1002/ar.a.20017.

65. Xanthakis V, Vasan RS. Aldosterone and the risk of hypertension. Curr Hypertens Rep. 2013 Apr;15(2):102-7. doi: 10.1007/s11906-013-0330-y. PMID: 23378101; PMCID: PMC3619380.

66. Funder JW. Apparent mineralocorticoid excess. J Steroid Biochem Mol Biol. 2017 Jan;165(Pt A):151153. doi: 10.1016/j.jsbmb.2016.03.010. Epub 2016 Mar 5. PMID: 26956190.

67. Frey FJ, Odermatt A, Frey BM. Glucocorticoid-mediated mineralocorticoid receptor activation and hypertension. Curr Opin Nephrol Hypertens. 2004 Jul;13(4):451-8. doi:

10.1097/01.mnh.0000133976.32559.b0. PMID: 15199296.

68. Chapman K, Holmes M, Seckl J. 11ß-hydroxysteroid dehydrogenases: intracellular gate-keepers of tissue glucocorticoid action. Physiol Rev. 2013;93(3):1139-1206. doi:10.1152/physrev.00020.2012.

69. Funder J. 30 YEARS OF THE MINERALOCORTICOID RECEPTOR: Mineralocorticoid receptor activation and specificity-conferring mechanisms: a brief history. J Endocrinol. 2017 Jul;234(1):T17-T21 . doi: 10.1530/JOE-17-0119. Epub 2017 May 22. PMID: 28533421.

70. Fuller PJ, Yao YZ, Yang J, Young MJ. Structural determinants of activation of the mineralocorticoid receptor: an evolutionary perspective. J Hum Hypertens. 2021 Feb;35(2):110-116. doi: 10.1038/s41371-020-0360-2. Epub 2020 May 28. PMID: 32467588.

71. Hilser VJ, Thompson EB. Structural dynamics, intrinsic disorder, and allostery in nuclear receptors as transcription factors. J Biol Chem. 2011;286(46):39675-39682. doi:10.1074/jbc.R111.278929.

72. Changeux JP, Christopoulos A. Allosteric Modulation as a Unifying Mechanism for Receptor Function and Regulation. Cell. 2016 Aug 25;166(5):1084-1102. doi: 10.1016/j.cell.2016.08.015. PMID: 27565340.

73. Oka K, Hoang A, Okada D, Iguchi T, Baker ME, Katsu Y. Allosteric role of the amino-terminal A/B domain on corticosteroid transactivation of gar and human glucocorticoid receptors. J Steroid Biochem Mol Biol. 2015;154:112-119. doi:10.1016/j.jsbmb.2015.07.025. 


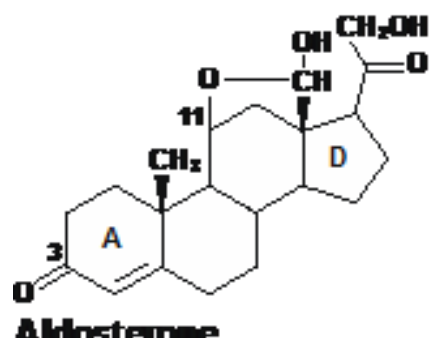

Adostelome

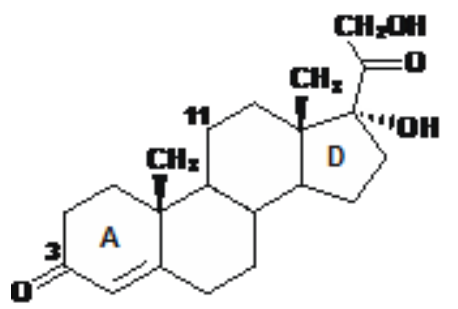

11-Deorycatitad

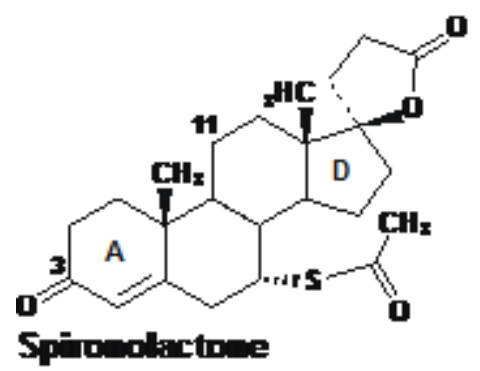

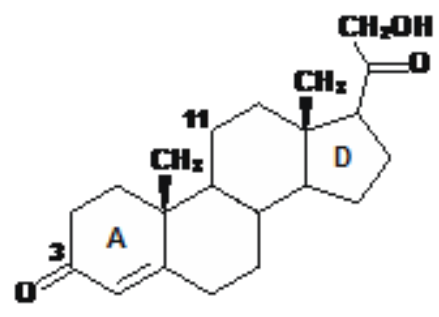

11-Deoxyconticosteone

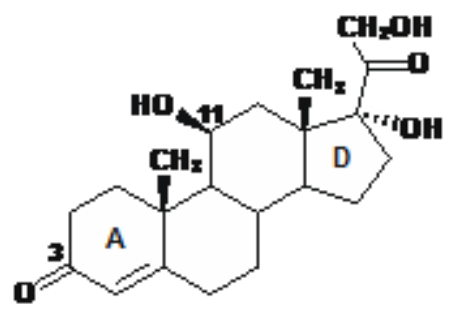

Contisol

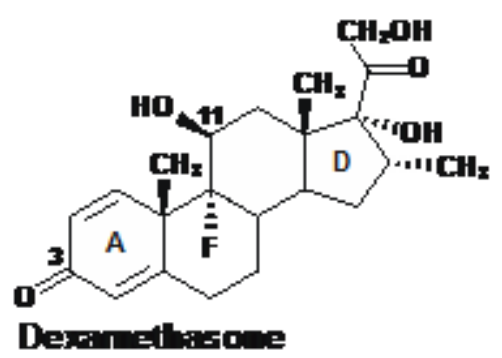

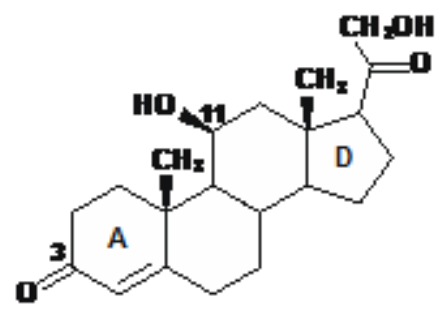

Coticosterome
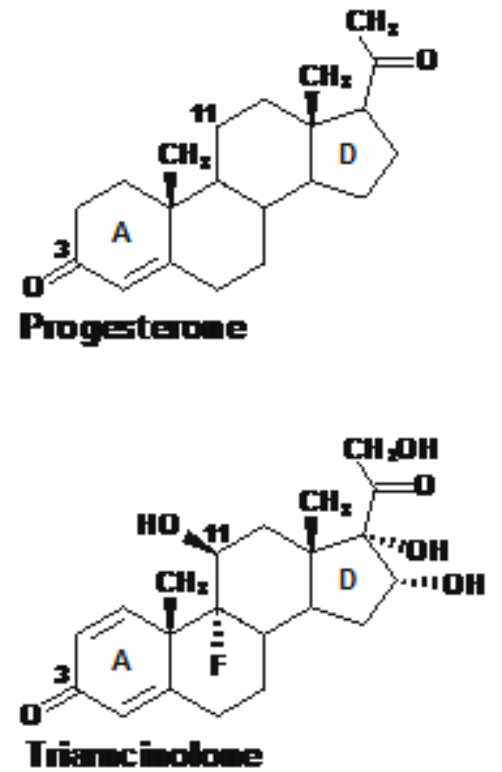

Figure 1

Structures of Corticosteroids, Dexamethasone, Triamcinolone, Progesterone and Spironolactone. Aldosterone and11-deoxycorticosterone are mineralocorticoids [41]. 11-deoxycortisol is a mineralocorticoid in lamprey [42,43]. Cortisol and corticosterone are glucocorticoids in terrestrial vertebrates and ray-finned fish $[41,44]$. Dexamethasone and triamcinolone are synthetic glucocorticoids. Progesterone is female reproductive steroid that also is important in male physiology $[45,46]$. Spironolactone is a mineralocorticoid antagonist in humans $[47,48]$. 


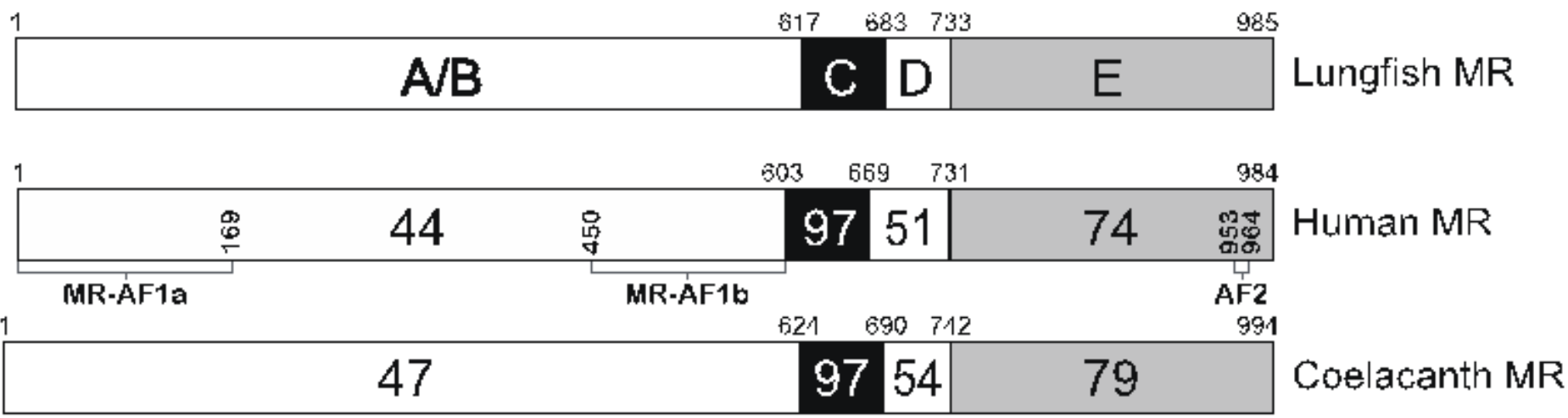

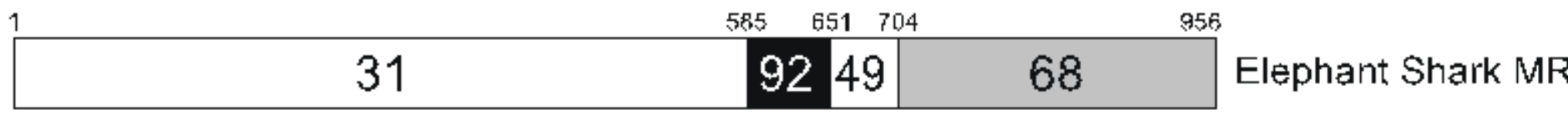

\begin{tabular}{|c|c|c|c|}
\hline 43 & 9551 & 73 & Xenopus MR \\
\hline 1 & 56771 & & \\
\hline 34 & 10042 & 75 & Zebrafish MR \\
\hline
\end{tabular}

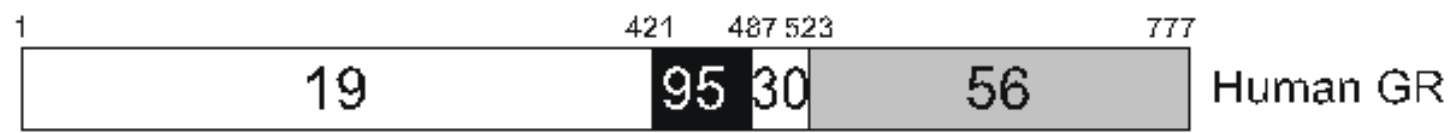

\begin{tabular}{|c|c|c|c|}
\hline & $16 \quad 483520$ & & \\
\hline 20 & 9532 & 57 & Coelacanth GR \\
\hline & 15 & & \\
\hline 21 & 9538 & 60 & Elephant Shark GR \\
\hline
\end{tabular}

Figure 2

Comparison of the functional domains of lungfish MR to corresponding domains in selected vertebrate MRs (human, coelacanth, elephant shark, Xenopus, zebrafish) and GRs (human, coelacanth, elephant shark). Lungfish MR and human MR have $97 \%$ and $74 \%$ identity in DBD and LBD, respectively. Lungfish MR and elephant shark MR have $92 \%$ and $68 \%$ identity in DBD and LBD, respectively. This strong conservation of the DBD and LBD contrasts with the low sequence identity of $44 \%$ and $47 \%$ between their NTDs. There are similar \% identities between corresponding domains in lungfish MR and other MRs. 
A. FulHength lungilsh MR with MMTV

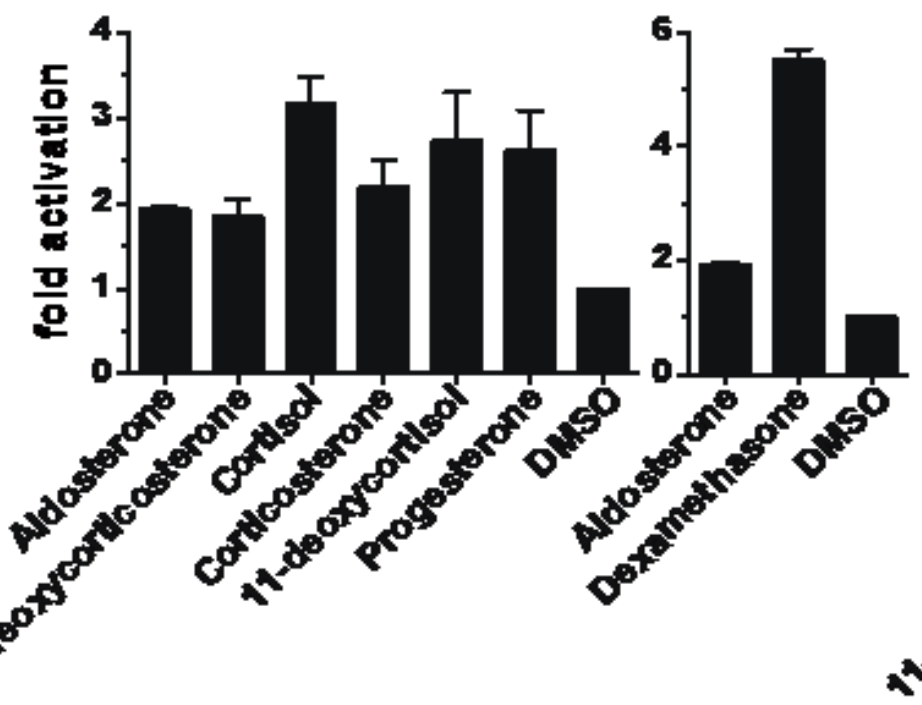

\section{FuHength lunglish $M R$ with TAT3}

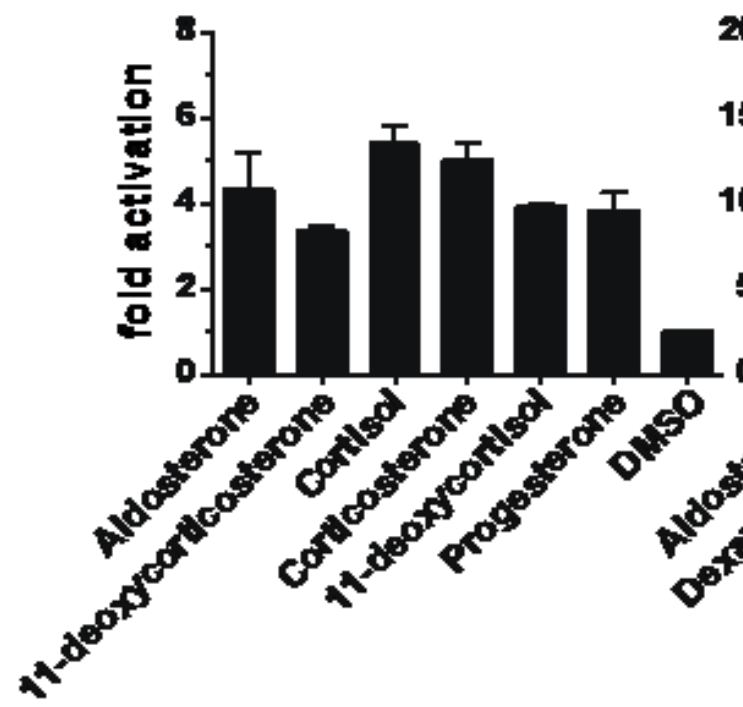

B. Truncated lunglish MR with MMTV

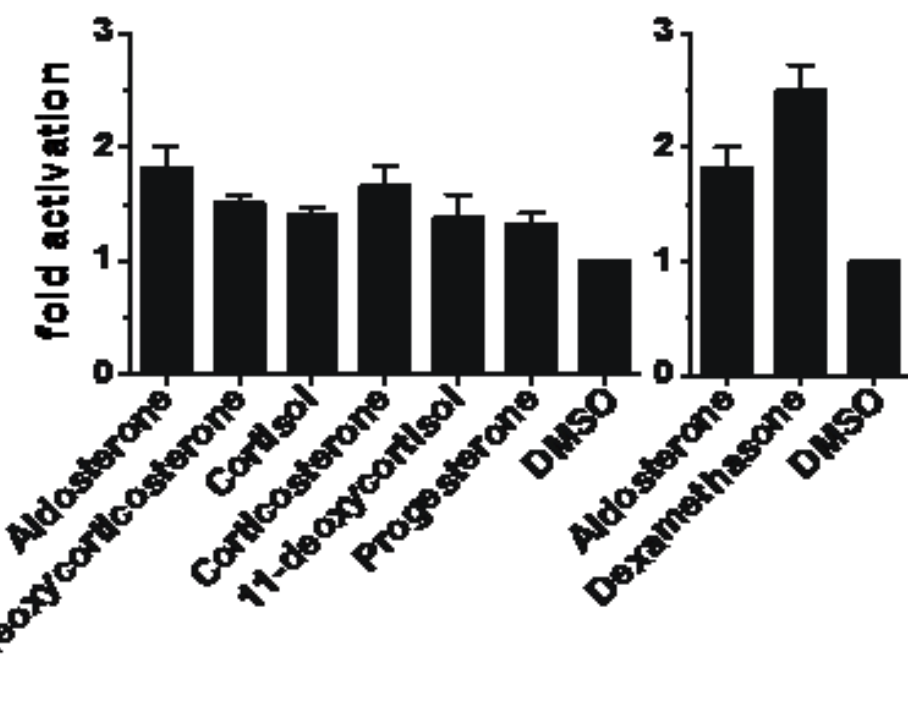

D. Truncated lunglish $M R$ with TAT3

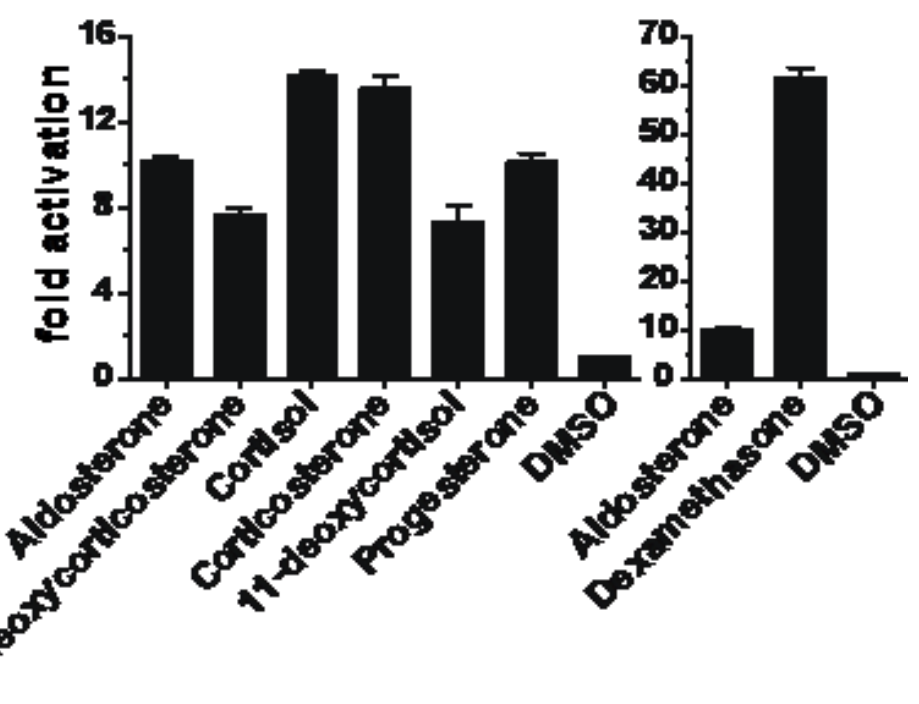

[10 nM Steroid]

Figure 3

Ligand specificity of full-length and truncated lungfish MR. Plasmids for full-length lungfish MR or truncated lungfish MR (MR-CDE) were expressed in HEK293 cells with an MMTV-luciferase reporter or a TAT3-luciferase reporter. Transfected cells were treated with either $10 \mathrm{nM}$ aldosterone, cortisol, 11deoxycortisol, corticosterone, 11-deoxycorticosterone, progesterone, dexamethasone or vehicle alone (DMSO). Results are expressed as means $\pm S E M, n=3$. $Y$-axis indicates fold-activation compared to the activity of control vector with vehicle alone as 1. A. Full-length lungfish MR with MMTV-luciferase. B. Truncated lungfish MR (MR-CDE) with MMTV-luciferase. C. Full-length lungfish MR with TAT3-luciferase. D. Truncated lungfish MR (MR-CDE) with TAT3-luciferase. 


\section{A. Lunglish MR-fun with TAT3}

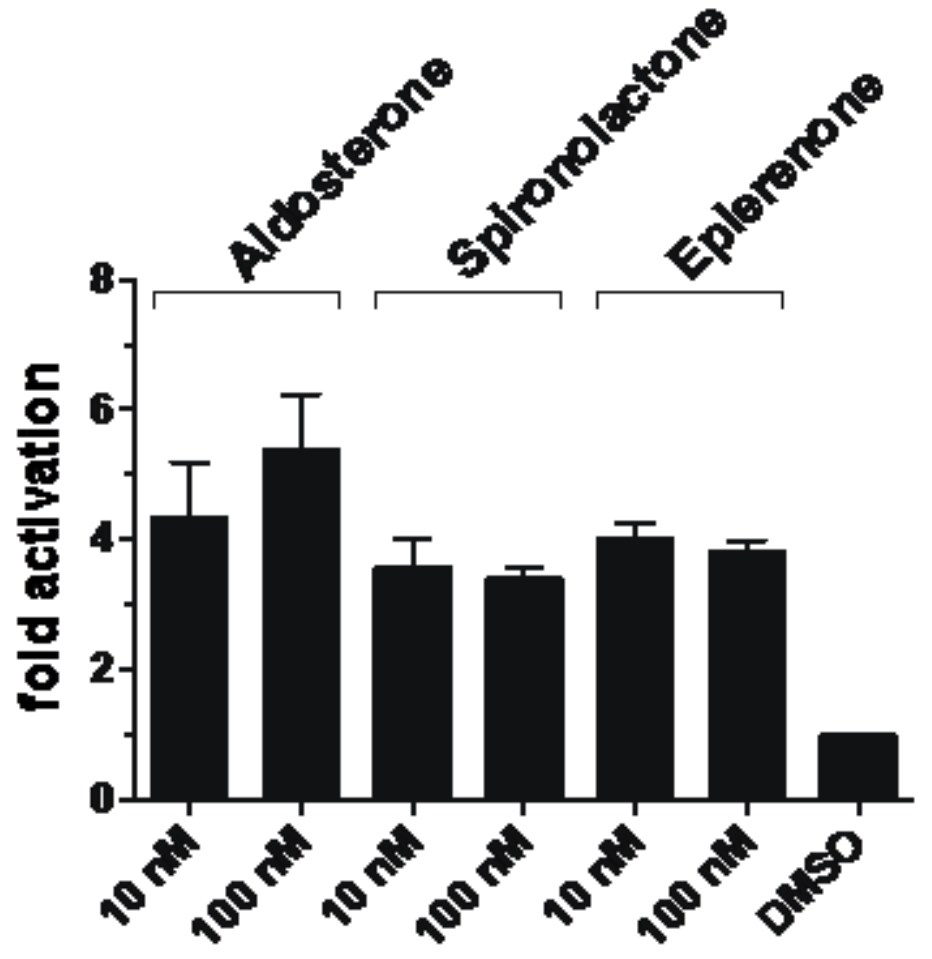

B. Lunglish MR-CDE with TAT3

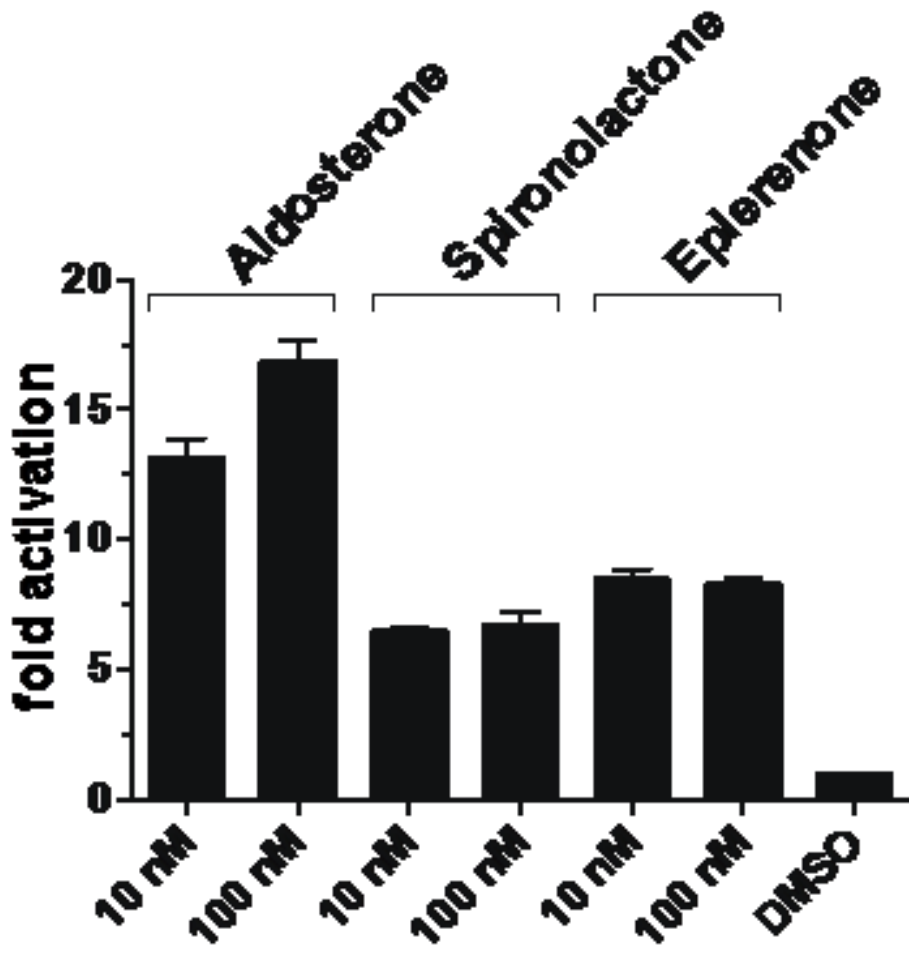

Figure 4

Spironolactone and eplerenone activation of full-length and truncated lungfish MR. Plasmids for fulllength lungfish MR or truncated lungfish MR (MR-CDE) were expressed in HEK293 cells with a TAT3luciferase reporter. Transfected cells were treated with either $10 \mathrm{nM}$ or $100 \mathrm{nM}$ aldosterone, spironolactone or eplerenone or vehicle alone (DMSO). Results are expressed as means \pm SEM, $n=3$. Yaxis indicates fold-activation compared to the activity of control vector with vehicle alone as 1 . A. Fulllength lungfish MR with TAT3. B. Truncated lungfish MR (MR-CDE) with TAT3. 
A: Fullength lungish HR with TAT3

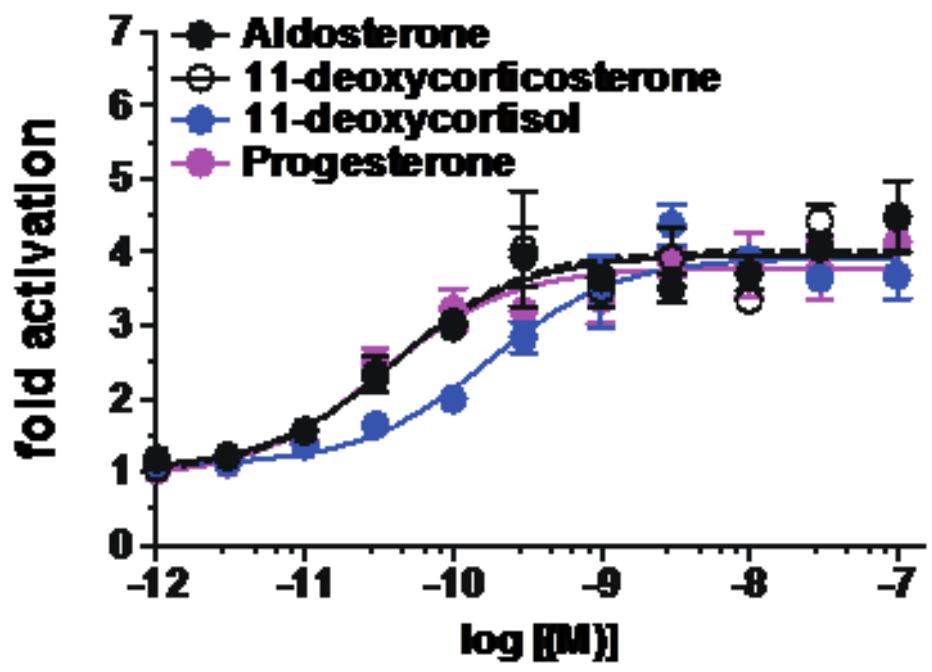

C: Fullength lungish MR with TAT3

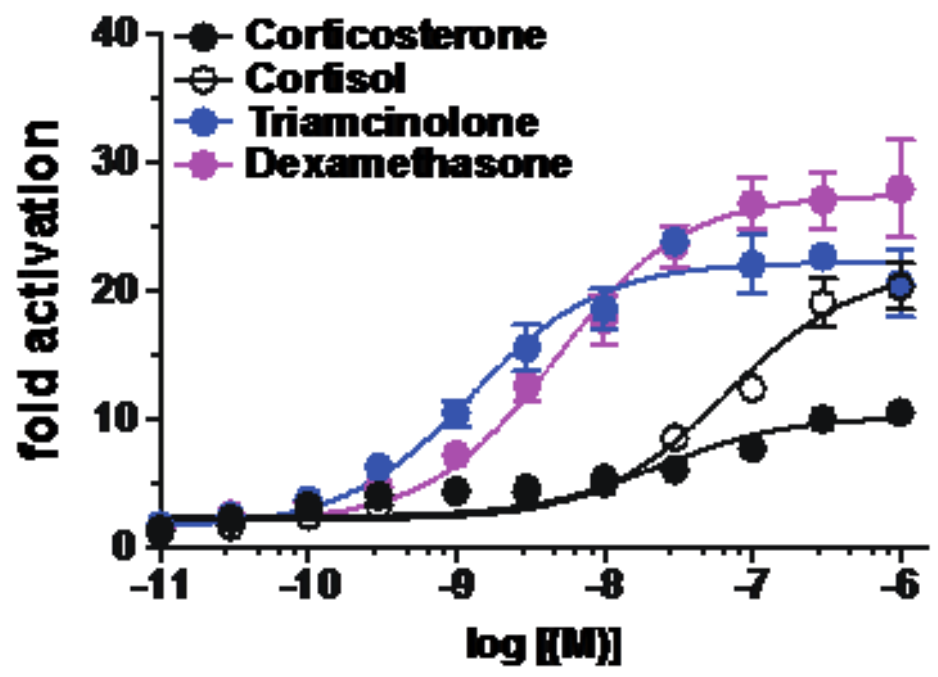

B: Truncated lunglish MR with TAT3

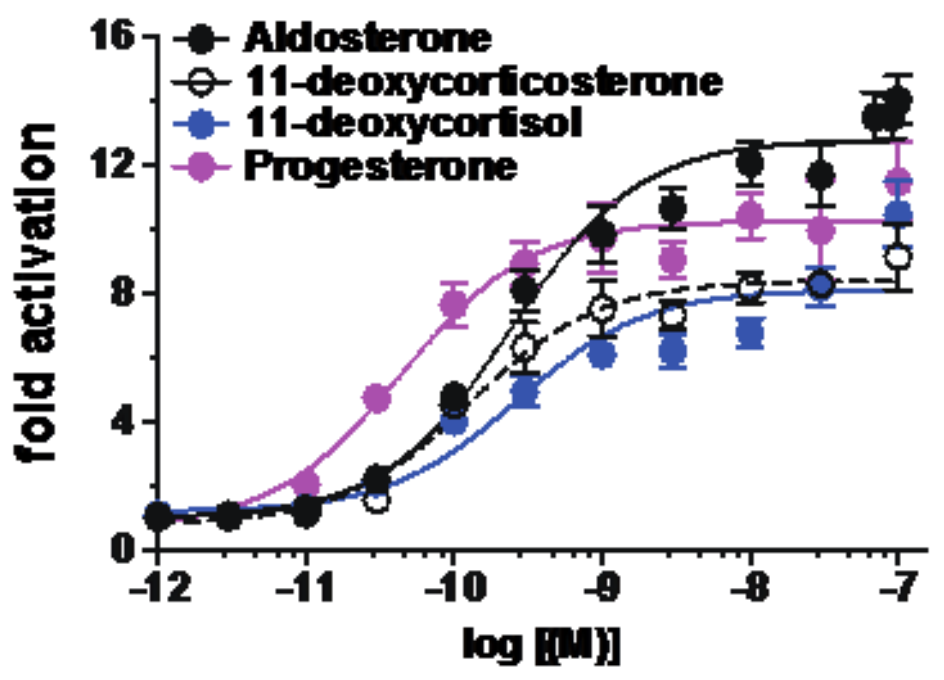

D: Truncated lunglish MR with TAT3

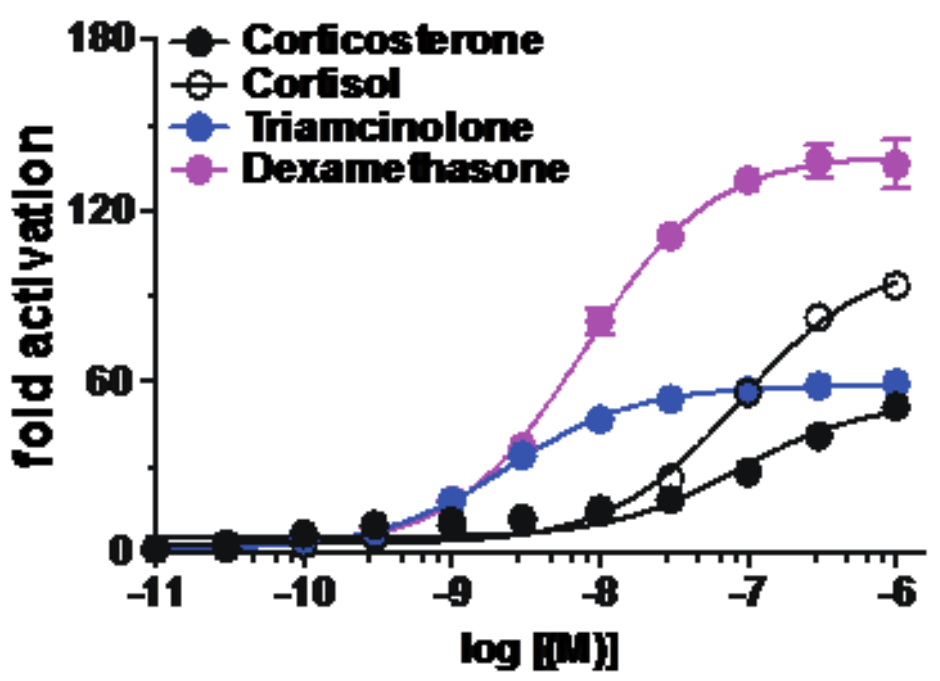

Figure 5

Concentration-dependent transcriptional activation by corticosteroids, progesterone, dexamethasone and triamcinolone of full length and truncated lungfish MR. Plasmids for full-length lungfish MR or truncated lungfish MR, were expressed in HEK293 cells with a TAT3-luciferase promoter. Cells were treated with increasing concentrations of either aldosterone, cortisol, corticosterone, 11-deoxycorticosterone, 11deoxycortisol, progesterone, dexamethasone and triamcinolone or vehicle alone (DMSO). Results are expressed as means $\pm S E M, n=3$. $Y$-axis indicates fold-activation compared to the activity of control vector with vehicle (DMSO) alone as 1. A. Aldosterone, 11-deoxycorticosterone, 11-deoxycortisol and progesterone with full-length lungfish MR with TAT3-luc. B. Aldosterone, 11-deoxycorticosterone, 11deoxycortisol and progesterone with truncated lungfish MR (Domains CDE) with TAT3-luc. C. Cortisol, corticosterone, dexamethasone and triamcinolone with full-length lungfish MR with TAT3-luc. D. Cortisol, corticosterone, dexamethasone and triamcinolone with truncated lungfish MR (Domains CDE) with TAT3luc. 
A. Fullength human $1 R$ with MuTV

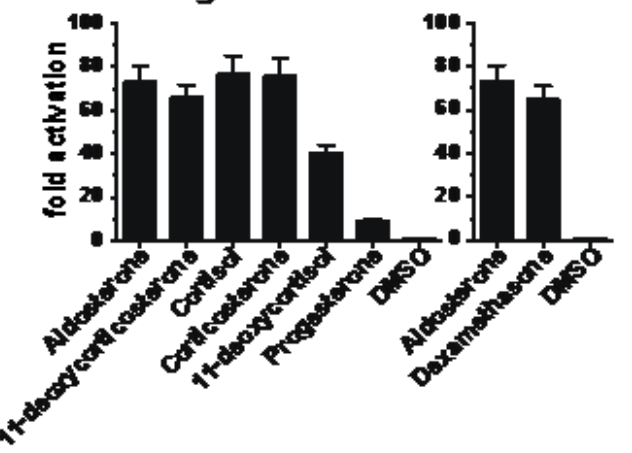

C. Ful-Hength human IR with TA T3
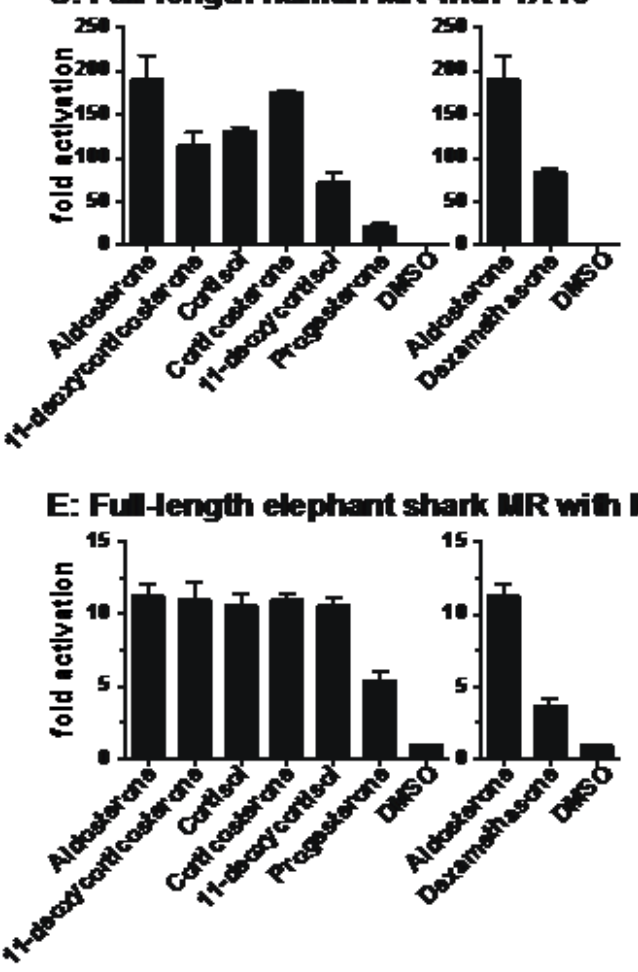

G: Ful-length elephant shark MR with TAT3

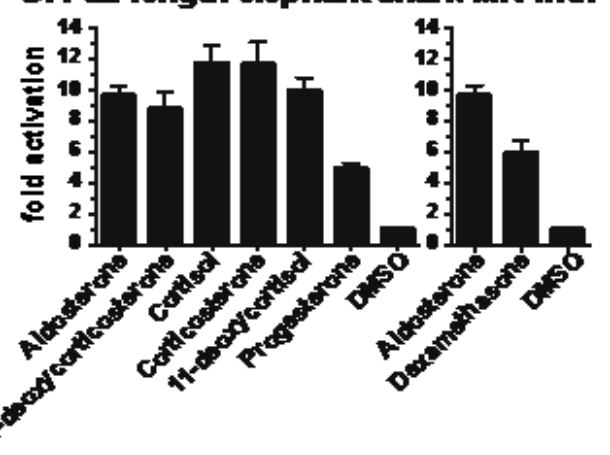

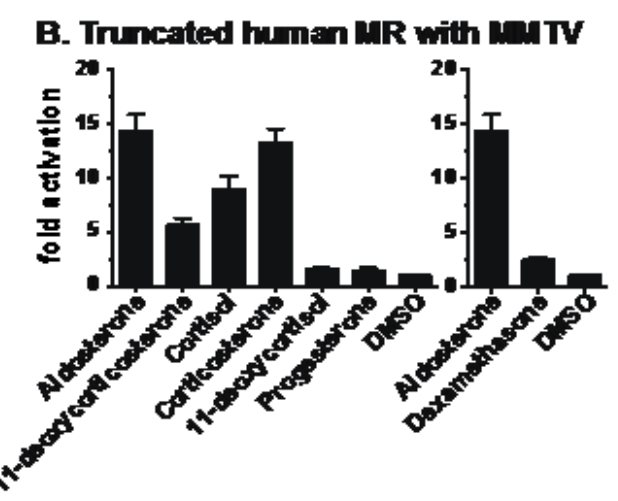
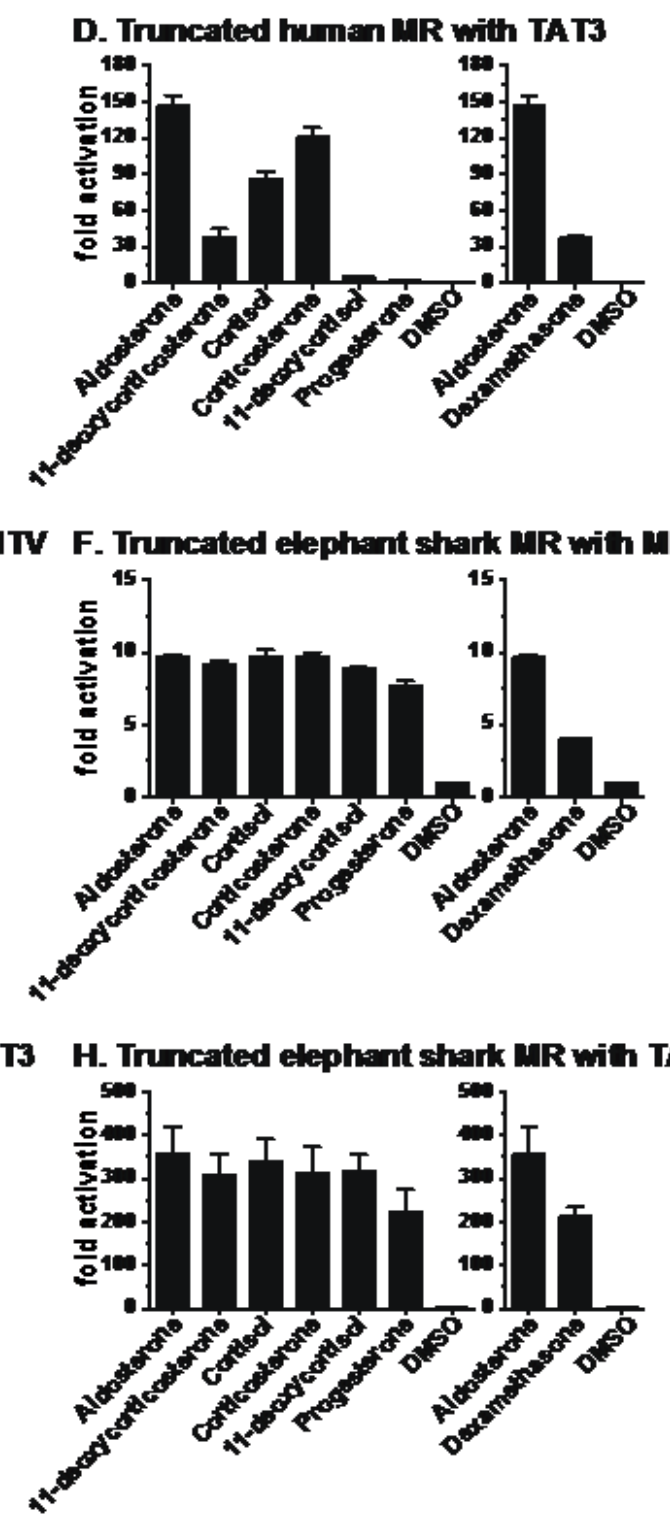

Figure 6

Ligand specificity of full-length and truncated human MR and elephant shark MR. Plasmids for full-length human and elephant shark MR or truncated human and elephant shark MR (MR-CDE) were expressed in HEK293 cells with an MMTV-luciferase reporter or a TAT3-luciferase reporter. Transfected cells were treated with either $10 \mathrm{nM}$ aldosterone, cortisol, 11-deoxycortisol, corticosterone, 11-deoxycorticosterone, progesterone, dexamethasone or vehicle alone (DMSO). Results are expressed as means $\pm S E M, n=3$. Y- 
axis indicates fold-activation compared to the activity of control vector with vehicle alone as 1. A. Fulllength human MR with MMTV-luciferase. B. Truncated human MR (MR-CDE) with MMTV-luciferase. C. Full-length elephant shark MR with TAT3-luciferase. D. Truncated elephant shark MR (MR-CDE) with TAT3-luciferase. 